\title{
miR-30e* is overexpressed in prostate cancer and promotes NF-кB-mediated proliferation and tumor growth
}

\author{
Shawn M. Egan ${ }^{1}$, Ellen Karasik ${ }^{2}$, Leigh Ellis ${ }^{3}$ and Sandra O. Gollnick ${ }^{4}$ \\ ${ }^{1}$ Department of Immunology, Roswell Park Cancer Institute, Buffalo, New York 14263, USA \\ ${ }^{2}$ Department of Pharmacology and Therapeutics, Roswell Park Cancer Institute, Buffalo, New York 14263, USA \\ ${ }^{3}$ Department of Oncologic Pathology, Dana-Farber Cancer Institute, Boston, MA 02215, USA \\ ${ }^{4}$ Department of Cell Stress Biology, Roswell Park Cancer Institute, Buffalo, New York 14263, USA \\ Correspondence to: Sandra O. Gollnick, email: Sandra.gollnick@roswellpark.org \\ Keywords: NF- $\kappa B$, microRNA, prostate cancer, cyclin D 1 \\ Received: December 30,2015 Accepted: June 02,2017 Published: June 28, 2017 \\ Copyright: Egan et al. This is an open-access article distributed under the terms of the Creative Commons Attribution License 3.0 \\ (CC BY 3.0), which permits unrestricted use, distribution, and reproduction in any medium, provided the original author and source \\ are credited.
}

\section{ABSTRACT}

According to the CDC prostate cancer (CaP) has the highest incidence and second highest mortality rate amongst cancers in American men. Constitutive NF- $\kappa$ B activation is a hallmark of CaP and this pathway drives many pro-tumorigenic characteristics of CaP cells, including cell proliferation and survival. An activated NF- $\mathrm{B}$ gene signature is predictive of CaP progression and biochemical recurrence following therapeutic intervention. However, the mechanisms that perpetuate NF-кB activation are incompletely understood. Genes that control NF- $\kappa$ B activity are rarely mutated in CaP suggesting that epigenetic mechanisms may contribute to constitutive NF-KB activation. microRNAs (miRs) epigenetically regulate many genes involved with

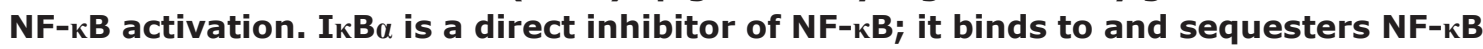
in the cytoplasm resulting in functional inhibition. $I_{\kappa} B \alpha$ is a target gene of $\mathrm{miR}-30 \mathrm{e}^{*}$ yet the expression and oncological impact of miR-30e* in CaP is unknown. We report that miR-30e* expression is elevated in multiple murine models of CaP and is most pronounced in late stage disease. miR-30e* drives CaP proliferation and tumor growth through inhibition of $I_{\kappa} B \alpha$, which results in chronic activation of NF-кB. Additionally, we show that inhibition of miR-30e* improves chemotherapeutic control of CaP. Thus, miR-30e* may prove to be a novel clinical target whose inhibition leads to decreased CaP cell proliferation and sensitization of CaP cells to chemotherapeutics.

\section{INTRODUCTION}

Prostate cancer $(\mathrm{CaP})$ is the most commonly diagnosed male cancer worldwide. Recent data from the American Cancer Society predicts that the estimated deaths from $\mathrm{CaP}$ are higher than any other cancer, except lung [1]. $\mathrm{CaP}$ is managed with a combination of prostatectomy, radiation, chemotherapeutics and androgen ablation [2]. While treatment of $\mathrm{CaP}$ can be curative, patients may experience biochemical recurrence and develop hormone refractory disease [2]. There are currently no curative options for hormone refractory disease; thus, new and novel treatment options are critically needed.
The precise mechanisms that drive the development of hormone refractory disease remain unknown; however, chronic inflammation and aberrant proliferation of prostate epithelial cells are believed to play a substantial role [3-5]. Nuclear factor- $\mathrm{kB}(\mathrm{NF}-\kappa \mathrm{B})$ activates cellular programs critical for cell survival, proliferation, and the induction of a robust inflammatory response through the expression of a number of genes [6,7]. NF- $\mathrm{KB}$ is a family of highly conserved homo and heterodimer transcription factors that are ubiquitously expressed in various cell types $[8,9]$. The NF- $\kappa \mathrm{B}$ family consists of 5 proteins; p65 (Rel A), c-Rel, Rel B, p50 (NFKB1) and p52 (NFKB2) [9]. Three separate pathways can activate NF- $\mathrm{KB}$ : the canonical pathway, the non-canonical pathway and the atypical pathway 
$[6,7]$. The canonical pathway involves the activation of p65:p50 heterodimers by IKK $\beta$. In the non-canonical pathway p52:Rel B heterodimers are activated when IKK $\alpha$ homodimers process $\mathrm{p} 100$ into active $\mathrm{p} 52$. The atypical pathway is characterized by IKK-independent dissociation of NF- $\kappa B$ from nuclear factor of $\kappa$ light polypeptide gene enhancer in B-cells inhibitor, alpha (IкB $\alpha)$.

Numerous factors regulate the initiation and duration of canonical NF- $\mathrm{KB}$ activation; the most dominant being the sequestration of NF- $\kappa B$ in the cytoplasm by $I \kappa B \alpha$ $[7,8,10]$. In resting cells, I $\kappa \mathrm{B} \alpha$ restrains NF- $\kappa \mathrm{B}$ in the cytoplasm; following an activation cue, I $\kappa \mathrm{B} \alpha$ becomes phosphorylated and subsequently ubiquitinated leading to its degradation $[7,8,10]$. Without the restraint of $\mathrm{I} \kappa \mathrm{B} \alpha$, $\mathrm{NF}-\kappa \mathrm{B}$ is able to translocate to the nucleus and promote target gene transcription. I $\kappa \mathrm{B} \alpha$ itself is an NF- $\mathrm{KB}$ target gene [9]. Thus, NF- $\kappa \mathrm{B}$ activation drives a negative feedback loop resulting in NF- $\mathrm{KB}$ being re-sequestered in the cytoplasm $[9,8,11]$. In spite of this negative feedback pathway, NF- $\mathrm{KB}$ is constitutively activated in many diseases including $\mathrm{CaP}[6,8-11]$. Constitutive activation of the canonical NF- $\mathrm{\kappa B}$ pathway is associated with a worse prognosis [12-14] and has been documented to be critical for chemotherapeutic resistance in $\mathrm{CaP}$ [15]. Furthermore, the expression of the NF- $\mathrm{kB}$ target genes, IL-6, VEGF, MMP9, and TNF- $\alpha$ are positively correlated with the extent and severity of $\mathrm{CaP}$. These genes also contribute to $\mathrm{CaP}$ initiation, growth, progression, and metastasis through the induction of chronic inflammation and angiogenesis $[4,16,17]$. Cyclin D1, another NF- $\kappa B$ target gene, is critical for continued $\mathrm{CaP}$ cell proliferation $[16,18]$. Although the role that NF- $\mathrm{KB}$ plays in $\mathrm{CaP}$ is well appreciated, the precise mechanisms facilitating constitutive NF- $\mathrm{KB}$ activation remain unknown. The mutation rate of genes encoding NF- $\mathrm{kB}$ and the molecules regulating its activation, such as I $\mathrm{KB} \alpha$, is low in clinical CaP samples $[19,20]$. Thus, epigenetics may contribute to constitutive NF- $\mathrm{\kappa B}$ activation.

microRNAs (miRs) are small RNA molecules approximately 20-25 nucleotides in length [21]. miRs bind to complementary target regions located predominately in the 3 ' untranslated regions of mRNA transcripts [21]. miRs regulate the expression of their target mRNA by translational repression and/or facilitating mRNA decay [22]. In $\mathrm{CaP}$, global miR dysregulation correlates with disease development, invasion and metastasis [23, 24]. Mounting evidence suggests that aberrant expression of miRs contributes to cell hyper-proliferation, apoptosis, chronic inflammation, and the induction of the stress response [23-25].

$\mathrm{NF}-\kappa \mathrm{B}$ activation is both directly and indirectly regulated by miRs. miRs specifically target $\mathrm{NF}-\kappa \mathrm{B}$ mRNA transcripts as well as alter the expression of genes that coordinate its activation $[9,26,27,28]$. An example is miR-30e* which inhibits IкB $\alpha$ [27]. In human glioma hyper-expression of miR-30 $\mathrm{e}^{*}$ constitutively drives
NF- $\kappa \mathrm{B}$ activation [27]. Yet the expression and biological impact of miR-30e* in $\mathrm{CaP}$ is unknown.

In this study we demonstrate that miR-30e* is over-expressed in murine models of $\mathrm{CaP}$. We show that miR-30e* drives $\mathrm{CaP}$ cell proliferation by targeting I $\mathrm{I} B \alpha$. Mechanistically, miR-30e* increases NF-KB activation, increases the expression of cyclin D1 which prompts the phosphorylation of $\mathrm{Rb}$, a critical regulator of $\mathrm{CaP}$ proliferation. Evaluation of the clinical significance of this finding revealed that targeting the miR30e*: IкB $\alpha$ axis can control prostate tumor growth. Additionally, pretreating $\mathrm{CaP}$ cells with a miR-30e* inhibitor sensitizes the cells to the chemotherapeutic docetaxel.

\section{RESULTS}

\section{miR-30 $e^{*}$ is overexpressed in murine models of prostate cancer}

The expression of miR-30e* was examined in two autochthonous experimental mouse models of $\mathrm{CaP}$; the TRansgenic Adenocarcinoma of the Mouse Prostate (TRAMP) model system and the HI-Myc model. The TRAMP model system is a probasin driven SV-40 TAg transformation model that manifests as prostate epithelial specific transformation [29]. The probasin promoter is activated in response to androgen, which is first produced when mice reach puberty at 4 weeks of age. Mice consistently develop prostatic intraepithelial neoplasia (PIN) by 6 weeks of age and then progress to macroscopic disease by 12-29 weeks of age [29]. miR-30e* expression was significantly higher in TRAMP prostates when compared to syngeneic age-matched C57BL/6 control prostates at multiple age points (Figure $1 \mathrm{~A} ; * P \leq 0.05$ ). To validate that elevated miR-30e* expression in $\mathrm{CaP}$ was not a model specific phenomenon, miR-30e* expression in the Hi-MYC transgenic $\mathrm{CaP}$ model [30] was also analyzed (Figure 1B). Hi-MYC mice develop PIN as early as 2 weeks of age and progress to macroscopic cancer by 6 months [31]. miR-30e* expression was significantly elevated in prostates isolated from Hi-MYC transgenic mice relative to aged-matched control prostates isolated from FVB mice. At ages which have been shown to be tumor bearing miR-30e* expression was significantly elevated compared to control mice ( $7 \& 9$ months; ${ }^{*} P \leq$ $0.05)$. There was also a significant difference between 7 and 9 months in experimental mice echoing the TRAMP data suggesting miR-30e* may increase with disease progression (Figure 1B; 7 vs 9 months, ${ }^{*} P \leq 0.05$ ).

\section{miR-30e* regulates prostate cancer cell viability}

Inhibition of miR-30e* reduced the viability of TRAMP C2H tumor cells, a cell line derived from the TRAMP model (Figure $2 \mathrm{~A} ; * * * * P \leq 0.001$ ). Similar results were observed when miR-30e* was inhibited in 
the human $\mathrm{CaP}$ cell line $\mathrm{PC} 3 \mathrm{M}$ (Figure 2B; day 1: **P $\leq 0.01$ and day 2 : $\left.{ }^{*} P \leq 0.05\right)$. Confirmation of miR-30e* inhibition was performed in both TRAMP C2H and PC3M cells (Supplementary Figure $1 \mathrm{~A} \& 1 \mathrm{~B} ;{ }^{*} P \leq 0.05$ $* * * \mathrm{P} \leq 0.001)$. To determine how miR-30e* regulated $\mathrm{CaP}$ cell viability, the effects of miR-30 * inhibition on cell senescence, death and proliferation were tested. Inhibition of miR-30 $\mathrm{e}^{*}$ had no effect on the expression of senescence-associated $\beta$-galactosidase (Figure 2C;
$* P>0.05$ ) or cleaved caspase-3 (Figure $2 \mathrm{D} ; * P>0.05$ ) suggesting that miR-30e* is not altering cell viability by inhibiting the percentage of cells that enter senescence or altering the rate of apoptotic cell death. miR-30e* inhibition did however significantly reduce the percentage Ki67 expressing cells (Figure $2 \mathrm{E}$; $* * P \leq 0.01$ ) suggesting that the decrease in the cell viability following miR-30e* inhibition (Figure 2A \& 2B) was due in part to a reduction in proliferation.

A

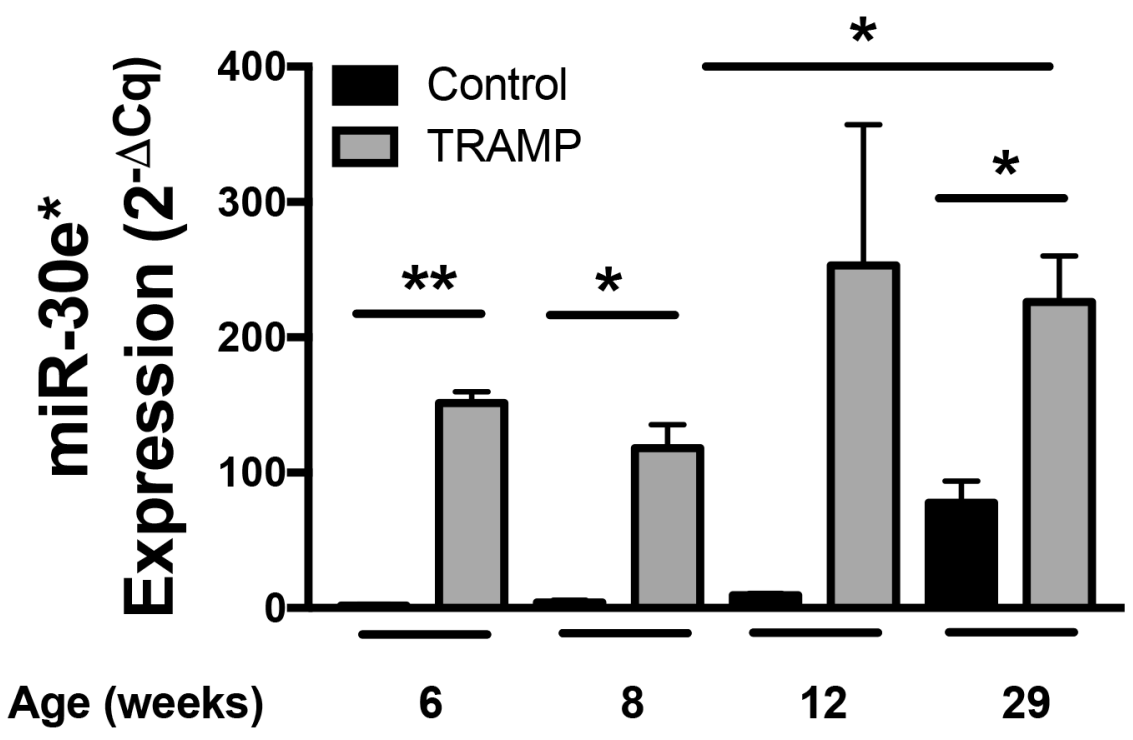

B

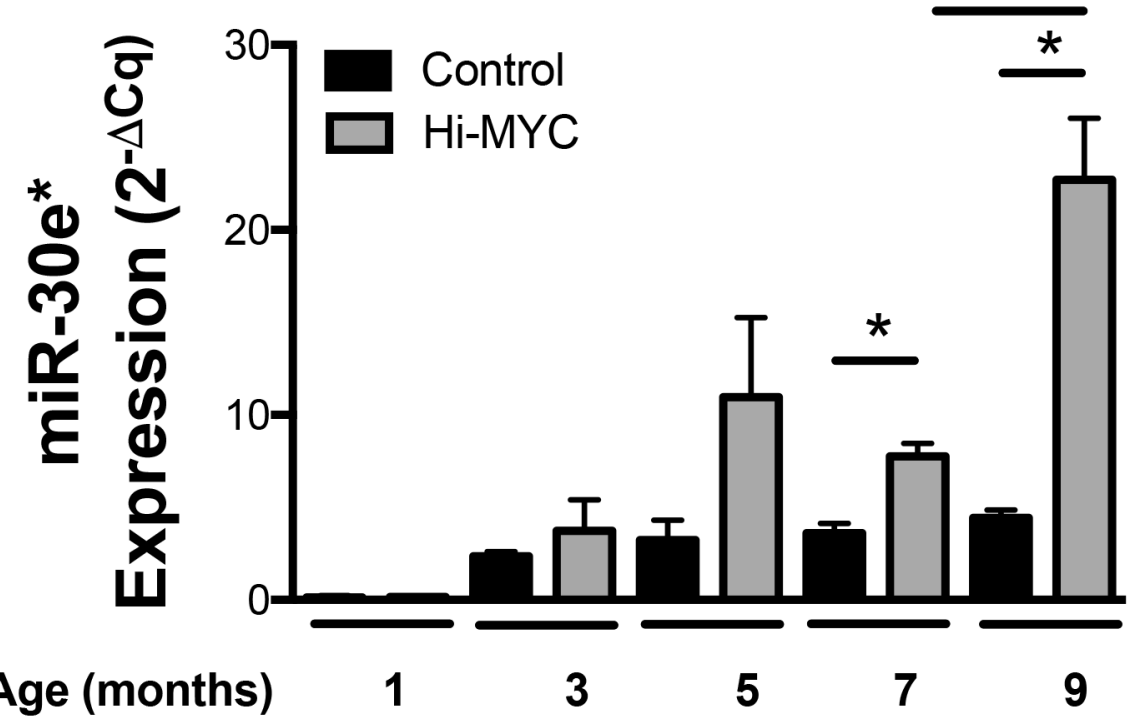

Figure 1: miR-30e* expression is elevated in CaP. (A) Whole prostates were harvested from TRAMP mice at 6-, 8-, 12 and 29-weeks of age and corresponding age matched control C57BL/6J mice $(\mathrm{n}=3)$. (B) Prostates were also harvested from Hi-MYC mice along with wild type FVB age matched control mice $(n=2)$. Prostates were analyzed for miR-30e* and U6 snRNA expression via qRTPCR. Raw data was analyzed and displayed in graph using the $2^{-\mathrm{dCq}}$ formula. Welch's t-test (A) and Student t-tests were performed (B), Error bars represent SEM; $* P \leq 0.05, * * P \leq 0.01$. 

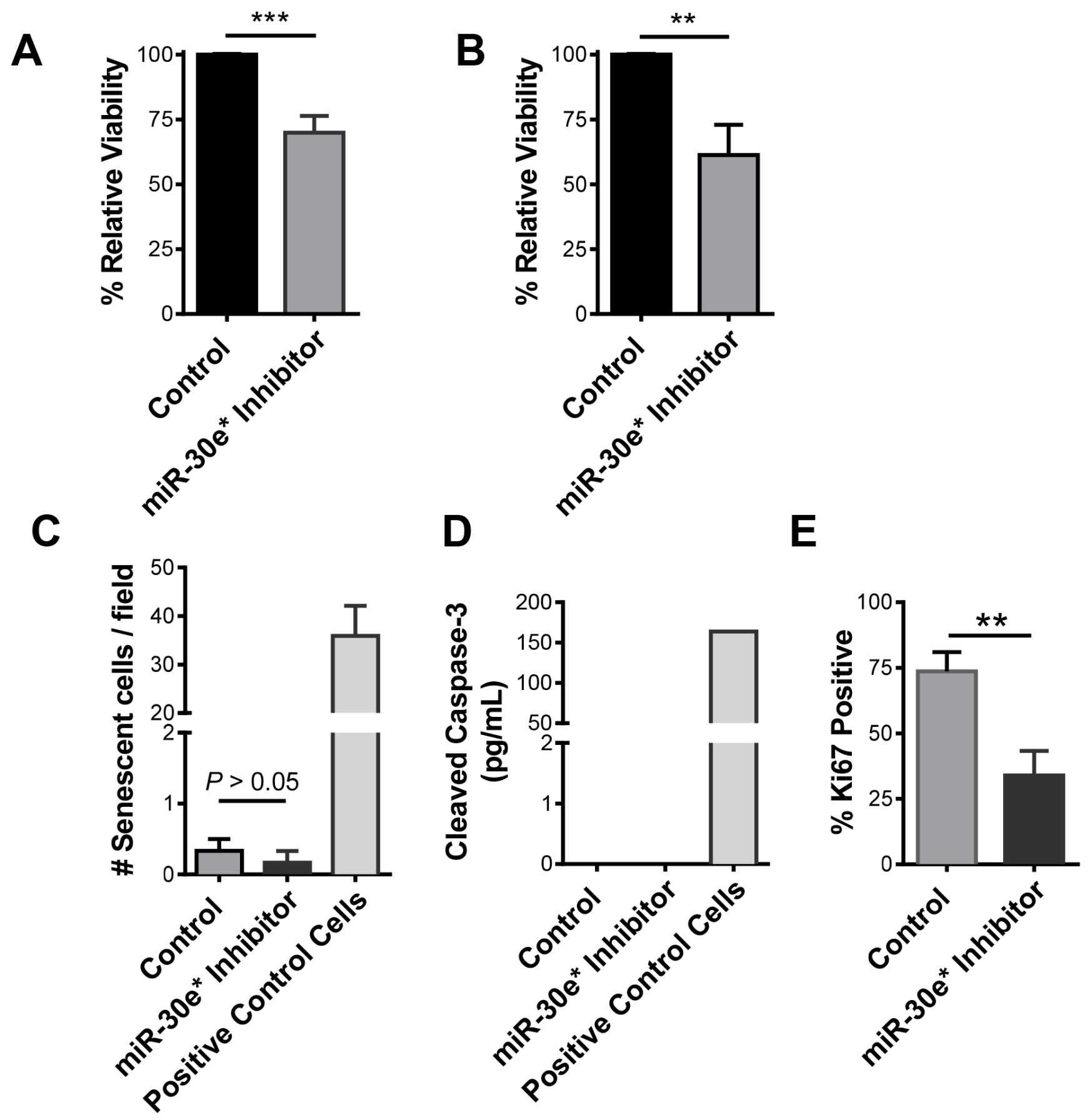

Figure 2: miR-30e* regulates CaP cell proliferation. (A) $\mathrm{C} 2 \mathrm{H}$ cells or (B) PC3M cells were transfected with either miR-30e* inhibitor oligos ( $\mathbf{a}$ ) or control scramble oligos. Twenty-four and forty-eight hours later MTT assays were performed. Results are reported as $\%$ viability relative to viability observed in cells transfected with control scramble oligos; each time point of the experiments was repeated a minimum of 4 times. Welch's t-tests were performed, Error bars represent SEM; $P \leq 0.05, * * P \leq 0.01, * * * P \leq 0.001, * * * * P$ $\leq 0.0001$. (C) Cell senescence was tested by staining either control or miR-30e* inhibited C2H cells for $\beta$-galactosidase, hydrogen peroxide treated fibroblasts were used as a positive control (Positive Control). Positively stained cells were analyzed in three separate 200x fields of view; counts were repeated 3 times and the average of the counts was recorded. Results are reported as \# of senescent cells / field. Welch's t-tests were performed, error bars represent SEM; $\mathrm{n}=3, P>0.05$. (D) Cell apoptosis was tested by detecting cleaved caspase-3 via ELISA in control or miR-30e* inhibited $\mathrm{C} 2 \mathrm{H}$ cells, TSA treated JAR cells were used as a positive control (Positive Control Cells). Results are reported as $\mathrm{pg} / \mathrm{mL}$ of cleaved caspase 3. Welch's t-tests were performed, error bars represent SEM; $\mathrm{n}=3, P>0.05$. (E) Cell proliferation was tested by IHC staining of Ki67 in control or miR-30e* inhibited C2H cells. Positively stained cells were analyzed using a light microscope in three separate 200x fields of view; counts were repeated 3 times and the average of the counts is presented as \% of Ki67 positive cells. Welch's t-tests were performed, error bars represent SEM; $\mathrm{n}=3, * P \leq 0.05$. 
miR-30e* regulates $\mathrm{NF}-\kappa \mathrm{B}$ activity which is essential for prostate cancer cell viability

$\mathrm{I} \kappa \mathrm{B} \alpha$ is a dominant inhibitor of the canonical NF$\kappa \mathrm{B}$ activation pathway. I $\mathrm{B} \alpha$ sequesters $\mathrm{p} 65: \mathrm{p} 50$ in the cytoplasm and is a confirmed target of miR-30e* [27]. Inhibition of miR-30 $\mathrm{e}^{*}$ led to a significant decrease in NF$\kappa \mathrm{B}$ activity (Figure $3 \mathrm{~A} ;{ }^{*} P \leq 0.05$ ). To assess whether NF$\kappa \mathrm{B}$ activation regulates prostate cancer cell viability and proliferation, TRAMP C2H and PC3M cells were treated

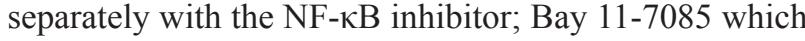
prevents the phosphorylation and subsequent degradation of I $\mathrm{B} \alpha$ (Figure 3B \& 3C). Treatment with Bay 11-7085 significantly reduced the percentage of viable cells in both TRAMP C2H and PC3M cells (Figure 3B; ** $\mathrm{P} \leq$ 0.01 , Figure $3 \mathrm{C} ; * \mathrm{P} \leq 0.05)$. Confirmation that Bay 118075 effectively inhibited I $\mathrm{B} \alpha \boldsymbol{\alpha}$ phosphorylation following LPS stimulation in both TRAMP C2H and PC 3M cells is depicted in Supplementary Figure 2.

\section{miR-30e* regulates prostate cancer cell proliferation and tumor growth through IкBa}

To determine whether the effects of miR-30e* inhibition on $\mathrm{CaP}$ cell proliferation were due to the direct inhibition of I $\mathrm{KB} \alpha$ by miR-30e*, TRAMP $\mathrm{C} 2 \mathrm{H}$ cells were transfected with a plasmid encoding a doxycycline inducible miR-30e* resistant I $\mathrm{I} B \alpha-\mathrm{HA}$ fusion protein (Figure 4A). Mutation of this miR-30e* seed sequence in the 3'UTR of I $\kappa \mathrm{B} \alpha$ was previously described by Jiang et al [27]. Functionality and doxycycline induction of the I $\mathrm{B} \alpha$-HA fusion protein are shown in Supplementary Figure 3A-3C. miR-30e* resistant IкB $\alpha$ TRAMP C2H cells were treated in vitro with doxycycline and viability was monitored via MTT assay. TRAMP $\mathrm{C} 2 \mathrm{H}$ cells transfected with wild type IкB $\alpha$ were used as a control. Cells expressing miR-30 $\mathrm{e}^{*}$ resistant I $\mathrm{I} \mathrm{B} \alpha$ exhibited a significant reduction in proliferation (Figure 4B; day 1: $* P \leq 0.05$, day $2: * P \leq 0.05$ and day $3: * * P \leq 0.01)$. To test whether the targeting of I $\mathrm{KB} \alpha$ by miR-30e* regulates $\mathrm{NF}-\kappa \mathrm{B}$ p65 nuclear translocation in vivo TRAMP $\mathrm{C} 2 \mathrm{H}$ cells expressing miR-30e* resistant I $\mathrm{I} B \alpha$ were injected subcutaneously into male C57BL/6 mice. When the tumors reached $100 \mathrm{~mm}^{3}$ the mice were randomized and fed either doxycycline chow or remained on normal chow. Doxycycline chow induced miR-30e* resistant IкB $\alpha$ while mice on normal chow maintained normal IкB $\alpha$ in the $\mathrm{CaP}$ cells. Tumors were explanted and assessed for nuclear NF- $\kappa B$ p 65 via IHC (Figure 4C). miR-30e* resistant I $\mathrm{BB} \alpha$ $\mathrm{C} 2 \mathrm{H}$ tumors displayed a significant reduction in nuclear NF- $\kappa \mathrm{B}$ p 65 relative to tumors from control chow fed mice (Figure $4 \mathrm{C}$; **** $P \leq 0.001$ ). This data confirms previous findings from Jiang et al. suggesting miR-30e* positively regulates NF- $\kappa \mathrm{B}$ activation through $\mathrm{I} \kappa \mathrm{B} \alpha$. To determine whether prostate tumor growth was negatively affected by inhibiting the interaction of miR-30e* with I $\mathrm{BB} \alpha$, miR-30e* resistant I $\mathrm{I} B \alpha$ tumor growth was assessed and compared to tumors from mice fed with normal control chow. TRAMP C2H tumor growth was delayed in mice that were fed doxycycline chow (Figure 4D) and the survival of these mice was significantly improved (Figure $4 \mathrm{E} ; P \leq 0.005)$. Doxycycline induction of miR-30e* resistant IKB $\alpha$ in the tumors was confirmed by western blot (Supplementary Figure 4).

\section{miR-30e* regulates cyclin D1 expression}

$\mathrm{NF}-\kappa \mathrm{B}$ affects cell proliferation through cyclin D1 [32], which regulates the G1-S phase transition [33]. Consistent with decreased NF- $\mathrm{BB}$ activity and cell
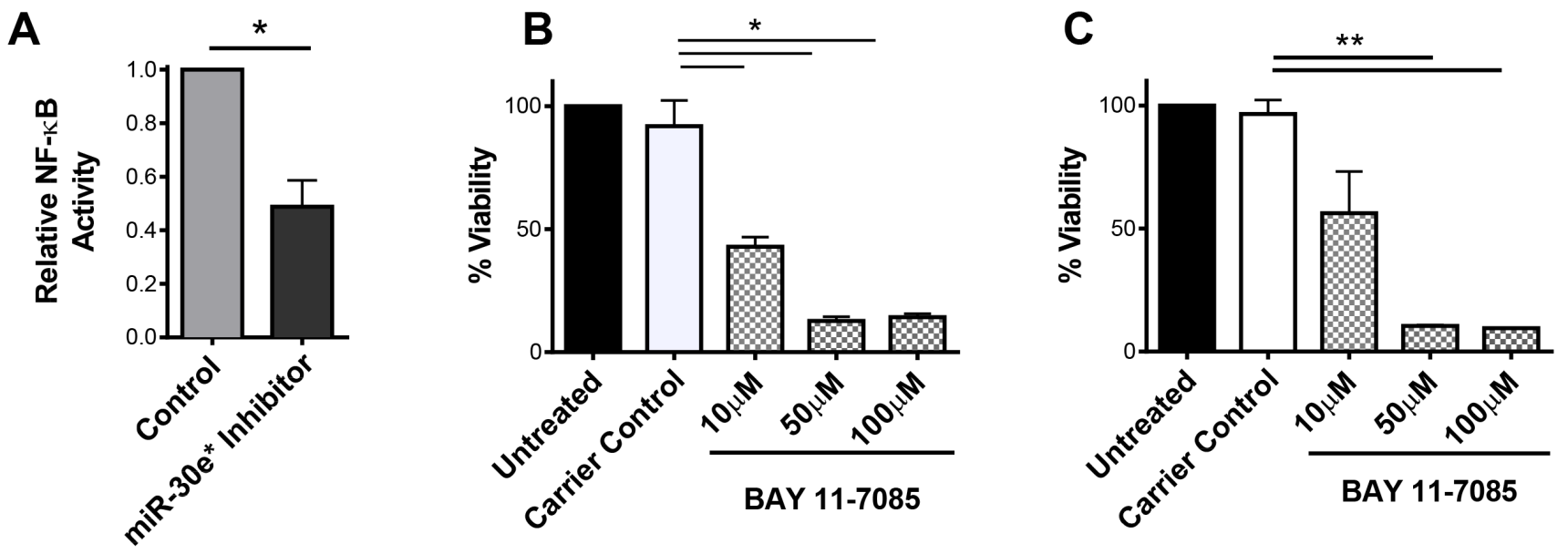

Figure 3: miR-30e* regulates $\mathrm{NF}-\kappa \mathrm{B}$ activity which is essential for prostate cancer cell viability. (A) To evaluate NF- $\mathrm{B}$ activation, an NF- $\mathrm{kB}$ luciferase reporter construct was transfected into $\mathrm{C} 2 \mathrm{H}$ cells. Luciferase was then evaluated in control and miR-30 $*$ inhibited cells 24 hours post inhibition. Results are depicted as NF- $\mathrm{kB}$ activity relative to control experimental group. Welch's t-tests were performed, error bars represent SEM; $\mathrm{n}=4, * P \leq 0.05$. To assess whether NF- $\mathrm{BB}$ regulates prostate cancer viability TRAMP C2H (B) and PC3M (C) cell viability was assessed following a 24 hour treatment with $10 \mu \mathrm{M}, 50 \mu \mathrm{M}$ and $100 \mu \mathrm{M}$ Bay 11-7085 treatment via MTT analysis. Equal volume ethanol carrier was used as a control. Welch's t-tests were performed, error bars represent SEM, $\mathrm{n}=3, * P \leq 0.05$ and $* * P \leq 0.01$. 
proliferation, a significant reduction in cyclin D1 protein expression was observed in vitro in miR-30e* inhibited TRAMP C2H cells (Figure $5 \mathrm{~A} ;{ }^{*} P \leq 0.05$ ). Cyclin D1 in complex with cyclin-dependent kinase (CDK) 4/6 phosphorylate the tumor suppressor gene retinoblastoma (Rb) allowing E2F to dissociate. Once freed, E2F translocates to the nucleus and drives S-phase protein expression which promotes the transition from $\mathrm{G} 1$ to $\mathrm{S}$ in the cell cycle [32]. miR-30e* inhibition reduced the levels of phosphorylated $\mathrm{Rb}$, but had no effect on total $\mathrm{Rb}$ expression levels (Figure $5 \mathrm{~B} ;{ }^{*} P \leq 0.05$ ). These findings suggest that miR-30 * positively regulates prostate tumor cell proliferation via the NF- $\kappa \mathrm{B}$ target gene cyclin-D1. To test this model in vivo, miR-30 * resistant $\mathrm{I} \kappa \mathrm{B} \alpha$ TRAMP C2H tumors as well as corresponding control tumors were immunohistochemically stained for Ki-67 and Cyclin D1 (Figure 5C \& 5D). miR-30e* resistant $\mathrm{I} \kappa \mathrm{B} \alpha$ TRAMP $\mathrm{C} 2 \mathrm{H}$ tumors expressed significantly less $\mathrm{Ki}-67$ and cyclin D1 suggesting the miR-30e*: IкB $\alpha$ axis regulates proliferation though the $\mathrm{NF}-\kappa \mathrm{B}$ target gene cyclin-D1 (Figure 5C \& 5D; *** $P \leq 0.005$ ).

In addition to its direct effects on cell proliferation, $\mathrm{NF}-\kappa \mathrm{B}$ can alter tumor growth and progression through activation of its target genes, including IL-6, VEGF, MMP9 and TNF- $\alpha[4,16,17]$. To test whether miR30e* could be altering the expression of other NF- $\kappa \mathrm{B}$ target genes in prostate cancer cells miR-30e* was inhibited and expression was assessed after 24 hours via qRTPCR. miR-30e* inhibition led to a significant decrease in the expression of TNF- $\alpha$ and VEGF mRNA as well as marginally reduced the expression of IL-10, IL-6 and iNOS (Supplementary Figure 5). MMP9 is another NF- $\kappa B$ target gene that functions to degrade extracellular matrix [27]. MMP9 has been demonstrated to enhance tumor cell invasion, angiogenesis and cell proliferation. Jiang et al [27] has shown that miR-30e* augments human glioma tumor growth by NF- $\kappa \mathrm{B}$ dependent regulation of MMP9 [27]. miR-30e* inhibition in TRAMP C2H cells did not significantly alter the expression of functional MMP9 (Supplementary Figure 6).

\section{miR-30e* inhibition sensitizes prostate cancer cells to docetaxel}

Docetaxel is the standard of care chemotherapeutic treatment for $\mathrm{CaP}$ and has been shown to improve life
A

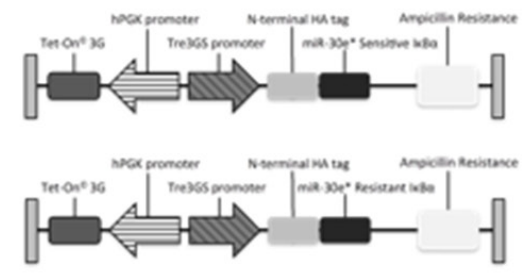

D

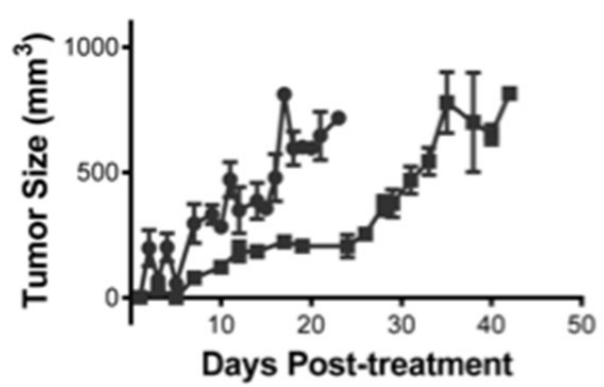

B

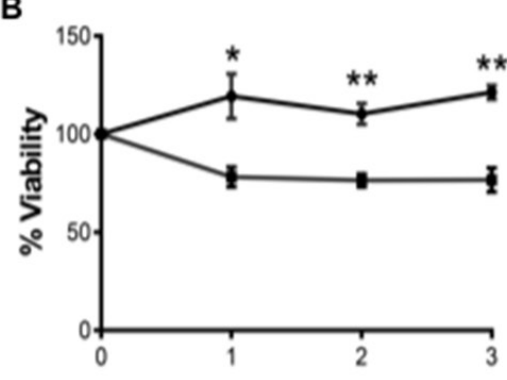

E Time in Doxycycline (Days)

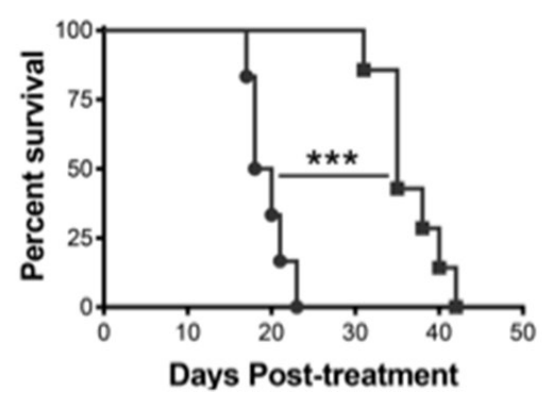

C
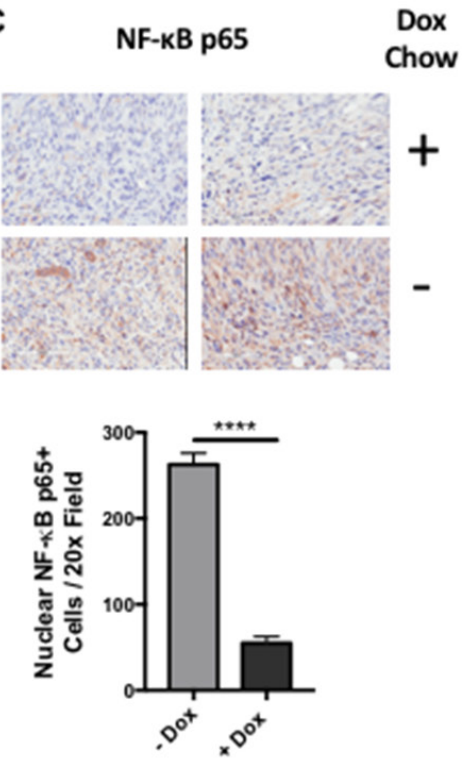

Figure 4: miR-30e* regulates prostate cancer cell proliferation and tumor growth through IkBa. (A) Plasmid maps for

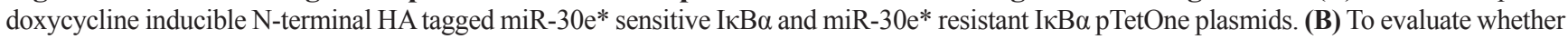
the miR-30 * : I $\mathrm{B} \alpha$ interaction regulates $\mathrm{CaP}$ cell proliferation, $\mathrm{C} 2 \mathrm{H}$ cells were transfected with a doxycycline inducible vector that expresses

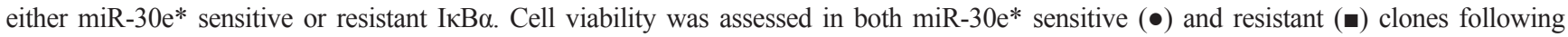
stimulation with $100 \mathrm{ng} / \mathrm{mL}$ doxycycline hyclate via MTT assay. Results are depicted as fold change relative cells not treated with doxycycline. Welch's t-tests were performed, error bars represent SEM; $\mathrm{n} \geq 3,{ }^{*} P \leq 0.05,{ }^{*} P \leq 0.01$. To determine if the specific targeting of IкB $\alpha$ by miR$30 \mathrm{e}^{*}$ regulated NF- $\mathrm{B}$ p 65 activation miR30e* resistant $\mathrm{I} \kappa \mathrm{B} \alpha \mathrm{C} 2 \mathrm{H}$ cells were administered subcutaneously in $\mathrm{C} 57 \mathrm{BL} / 6 \mathrm{mice}(\mathrm{C})$. Once the tumors reached $100 \mathrm{~mm}^{3}$, mice were randomized and initiated on either dox chow or remained on control chow. Tumor were explanted once the tumor volume reached $800 \mathrm{~mm}^{3}$ and nuclear NF- $\kappa$ B p 65 was quantified via IHC. Five sections were quantified from each tumor $(\mathrm{n}=4, P \leq 0.001)$. Normal $(\bullet)$ or doxycycline containing $(\boldsymbol{\square})$ chow tumors were monitored and tumor growth was assessed. Results are depicted as tumor growth $\left(\mathrm{mm}^{3}\right)$ after doxycycline treatment (D) and percent survival (E). Welch's t-tests were performed, error bars represent SEM; $\mathrm{n} \geq 6,{ }^{* * *} P \leq 0.001$. 
expectancy [34], yet it's efficacy as a monotherapy is blunted by its high toxicity [35]. Constitutive NF- $\mathrm{kB}$ activity contributes to docetaxel resistance in $\mathrm{CaP}$ [15]. Treatment of TRAMP C2H cells with docetaxel effectively decreased cell viability while combination treatment of docetaxel and miR-30 $*$ inhibition significantly enhanced docetaxel efficacy (Figure $5 \mathrm{E} ; * P \leq 0.05$ ), suggesting that inhibition of miR-30 $*$ increases $\mathrm{CaP}$ cell sensitivity to chemotherapeutics.

\section{DISCUSSION}

The goal of this study was to investigate whether miR-30e* contributed to constitutive NF- $\mathrm{kB}$ activation in $\mathrm{CaP}$. We report that miR-30e*, a NF- $\mathrm{kB}$ activating miR, is hyper-expressed in two murine models of autochthonous $\mathrm{CaP}$ relative to healthy controls. We further demonstrated that miR-30e* mediated hyper-activation of NF- $\kappa B$ contributes to $\mathrm{CaP}$ cell proliferation and viability. Our results indicated that the effects of miR-30e* in $\mathrm{CaP}$ cells are a result of miR-30e* inhibition of I $\mathrm{B} \alpha$ expression.
The model we propose (Figure 6) suggests that, miR$30 \mathrm{e}^{*}$ becomes hyper expressed in $\mathrm{CaP}$ cells as the disease progresses. miR-30 $e^{*}$ targets $I \kappa B \alpha$, thus increasing the level of free NF- $\mathrm{KB}$ to translocate to the nucleus. NF- $\mathrm{KB}$ drives the expression of cyclin D1, which in combination with $\mathrm{CDK} 4 / 6$, inactivates $\mathrm{Rb}$ enhancing $\mathrm{CaP}$ cells proliferation and decreases sensitivity to therapy.

Several studies support a role for miR-30e* in $\mathrm{NF}-\kappa \mathrm{B}$ driven cell proliferation and CaP. Lee et al. [35] demonstrated that a decrease in miR-30 ${ }^{*}$ expression correlated with a decrease in proliferation and viability of normal dermal papilla cells. Mortensen et al. [36] analyzed the miR profile in $\mathrm{CaP}$ patients prior to treatment. miR-30e* was significantly elevated in patients that eventually developed biochemical recurrence following treatment relative to patients who did not. A recent study [37] assessed the molecular profile of 333 primary prostate carcinomas as well as 27 adjacent normal tissues. The results suggest that the majority of primary prostate cancers fall under 7 subtypes which are defined by specific gene mutations/fusions. Analysis of a comprehensive list
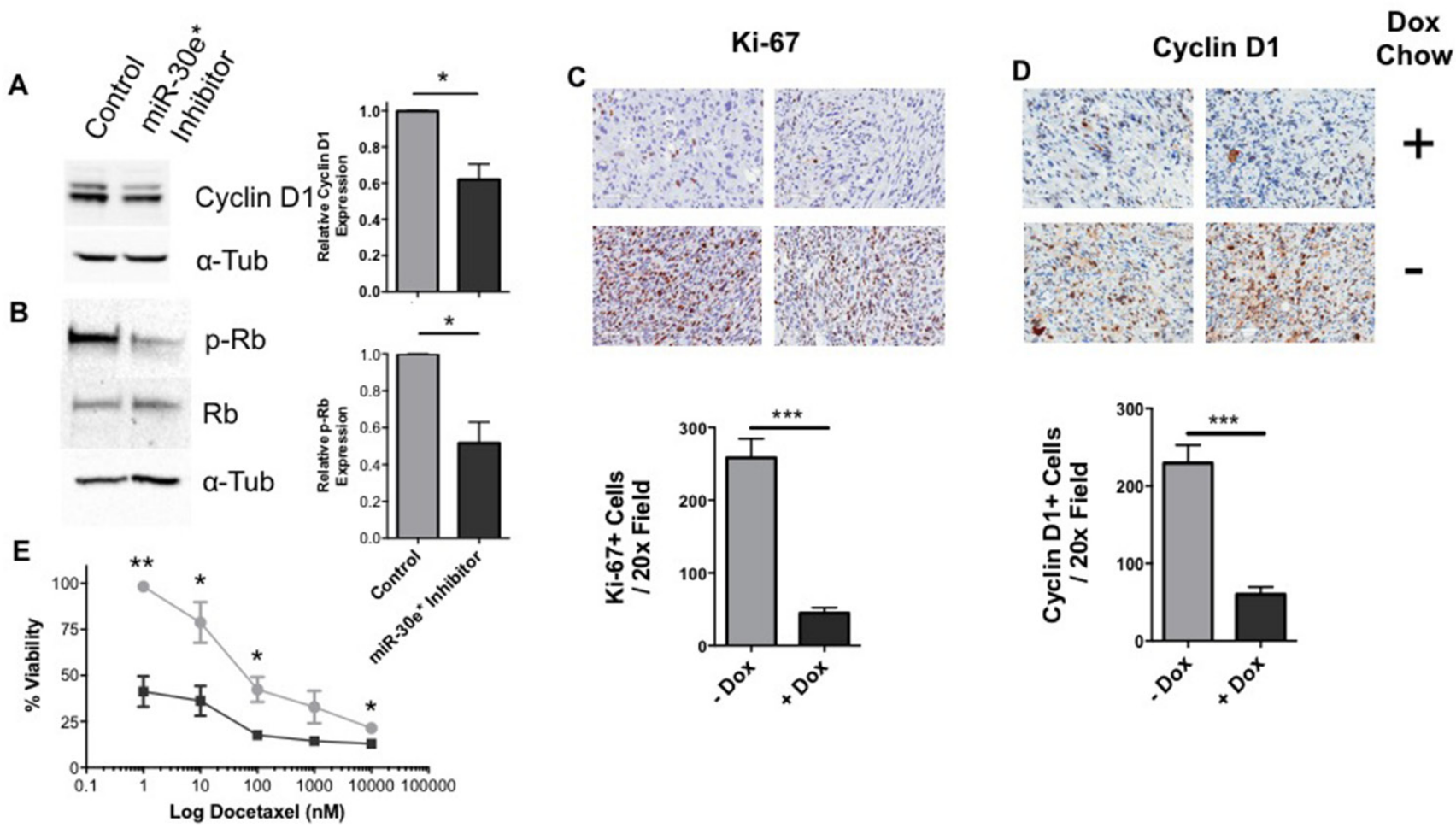

Figure 5: The miR-30e*: IкBa axis regulates cyclin $\mathrm{D} 1$ and proliferation in vivo. The expression of cyclin D1 (A) and Rb (total and phosphorylated) (B) were evaluated in $\mathrm{C} 2 \mathrm{H}$ cells treated with or without miR-30e* inhibitor for 24h via western blot analysis. Representative blots are shown on the right; summary results are depicted as expression relative to control C2H cells. Welch's t-tests were performed, error bars represent SEM; $\mathrm{n} \geq 4, * P \leq 0.05$. To assess if miR-30 $\mathrm{e}^{*}$ regulates prostate cancer cell proliferation and the expression of cyclin $\mathrm{D} 1$ in vivo IHC was performed. miR30e* resistant $\mathrm{I} \kappa \mathrm{B} \alpha \mathrm{C} 2 \mathrm{H}$ cells were administered subcutaneously in $\mathrm{C} 57 \mathrm{BL} / 6 \mathrm{mice}$. When the tumors had established and reached $100 \mathrm{~mm}^{3}$, normal $(\bullet)$ or doxycycline containing $(\boldsymbol{\square})$ chow was administered, tumors were harvested, formalin fixed and stained for Ki-67 (C) and cyclin D1 (D) when they reached $800 \mathrm{~mm}^{3}$. Images (C-D) represent IHC staining from 2x representative tumors from both normal and doxyxline chow fed mice and are displayed at 20x. (E) C2H cells were treated with either docetaxel alone $(\bullet)$ or in combination with miR-30e* inhibitor ( $\bullet$ ) and viability was assessed via MTT assays. Results are depicted as \% viable (absorbance value of experimental relative to untreated TRAMP C2H cells). Welch's t-tests were performed, error bars represent SEM; $\mathrm{n}=4, * P \leq 0.05, * * P \leq 0.01$. 
of microRNA in relation to these specific gene mutations revealed that miR-30 $\mathrm{e}^{*}$ was overexpressed relative to adjacent healthy tissue in all subtypes and was further elevated in 3/6 of the subtypes defined by having ERG, ETV1 and SPOP fusion proteins respectively. These studies support our finding that miR-30e* is overexpressed in prostate cancer.

Our work suggests that miR-30e* drives CaP progression directly via augmentation NF- $\kappa \mathrm{B}$ dependent tumor cell proliferation. In contrast, Jiang et al. [27] has shown that miR-30 * contributes to glioma growth and progression indirectly via an increase in $\mathrm{NF}-\kappa \mathrm{B}$ mediated expression of MMP9, which augments tumor angiogenesis. Inhibition of $\mathrm{miR}-30 \mathrm{e}^{*}$ in $\mathrm{CaP}$ cells did not lead to changes in MMP9, suggesting that the effects of miR-30e*/NF- $\kappa \mathrm{B}$ are cell-type specific and may be the result of different microenvironments or co-expression of different miRs.

The mechanisms that drive miR-30e* upregulation in $\mathrm{CaP}$ are unknown. miR-30 $\mathrm{e}^{*}$ gene expression has been ascribed to being driven by two different promoters. Patel et al. [38] suggests that miR30e is an intronic miR located within the nuclear factor $Y C(N F-Y C)$ gene however, it is unclear whether the $N F-Y C$ gene promoter or one of several cryptic promoters and possible transcription factor binding sites located within the $N F-Y C$ gene drive miR30e transcription. A separate study by Liao et al. [39] reports that miR-30e is driven off its own promoter and can be activated by $\beta$-catenin / TCF4. There is also evidence suggesting that the tumor suppressor gene $p 53$, a gene often mutated or lost in $\mathrm{CaP}$ [40], negatively regulates miR-30e* expression. Hosako et al investigated miR profiles from embryos deficient for $p 53^{-/}$and discovered increased expression of miR-30e* [41].

While our data demonstrates that NF- $\kappa \mathrm{B}$ activation by $\mathrm{miR}-30 \mathrm{e}^{*}$ directly regulates $\mathrm{CaP}$ cell proliferation, we also provide evidence that miR-30 * regulates other pathways important in CaP growth. TNF- $\alpha$ and VEGF both have been reported to contribute to prostate cancer. Serum TNF- $\alpha$ is a prognostic factor of disease burden and increases sensitivity to androgen post androgen ablation [17]. VEGF expression in prostate cancer correlates with clinical stage, Gleason score, tumor stage, progression, metastasis, and survival [42]. Traditionally, miRs alter mRNA networks and it would be naïve to think that miR$30 \mathrm{e}^{*}$ is an exception. According to microRNA.org, miR$30 \mathrm{e}^{*}$ has 7,931 predicted targets and a number of these predicted targets are known to play an important role in CaP progression. The tumor suppressor genes PTEN (Phosphatase and tensin homolog), JNK (c-Jun N-terminal kinase), RB1 as well as an additional inhibitor of NF- $\mathrm{NB}$, NKIRAS1 (NF- $\kappa \mathrm{B}$ inhibitor-interacting Ras-like protein 1) are among the putative miR-30e* targets. Wang et al. has demonstrated that a conditional deletion of PTEN in the prostate epithelium is sufficient to drive transformation and cancer progression [43]; while Hübner et al. indicate that JNK deletion in combination with PTEN deletion develop androgen-independent metastatic $\mathrm{CaP}$ more

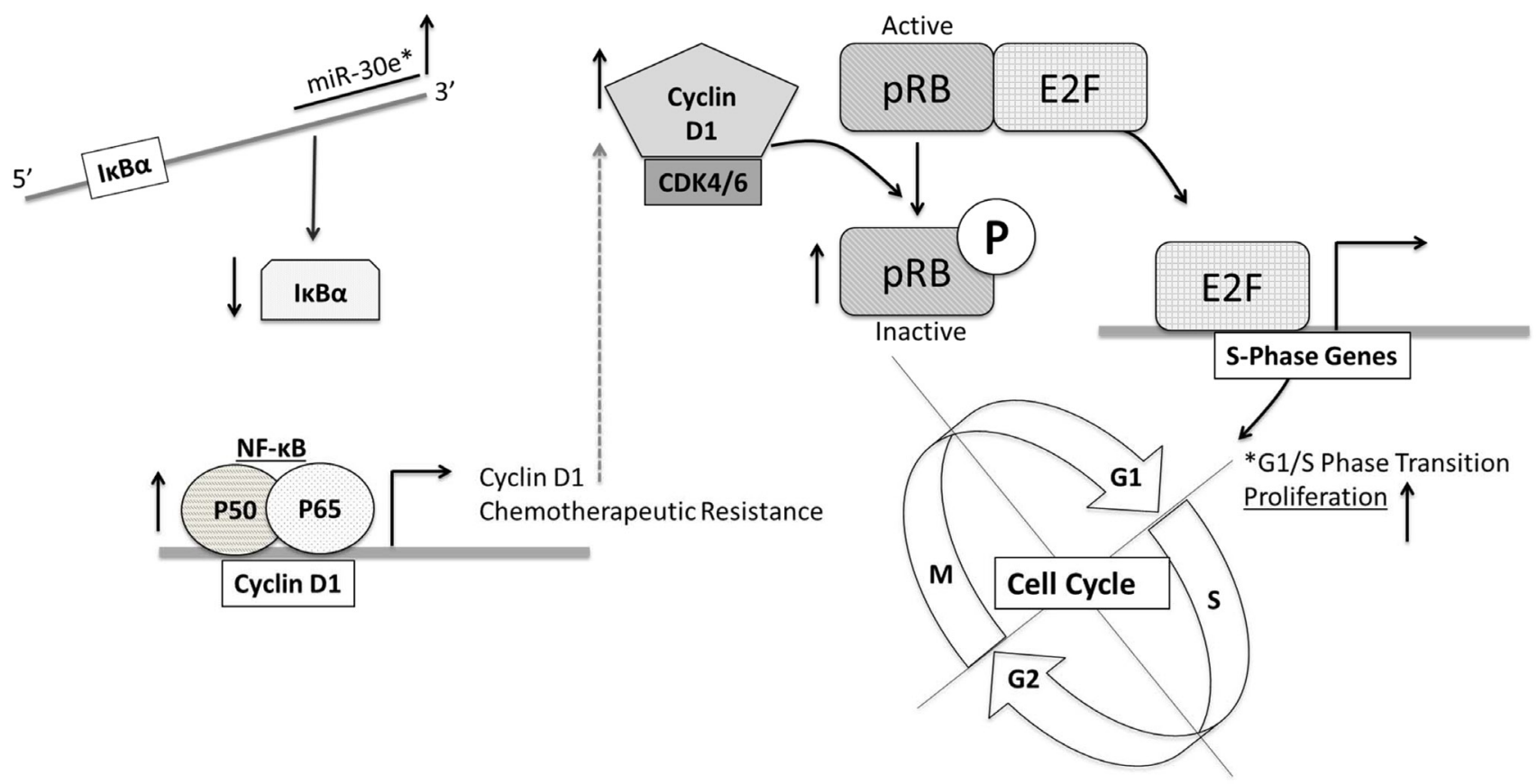

Figure 6: The microRNA-30e*: NF-KB axis regulates prostate cancer cell proliferation and therapeutic resistance. miR-30e* targets I $\kappa \mathrm{B} \alpha$ mRNA thus increasing NF- $\kappa$ B activation. NF- $\kappa$ B drives chemotherapeutic resistance and also increases cyclin D1 production. Cyclin D1:CDK4/6 phosphorylates pRb allowing it to dissociate from E2F. Free E2F pushes CaP cells from G1 to S phase and drives proliferation and therapeutic resistance. 
rapidly than the PTEN deletion alone [44]. Rb1 is a vital tumor suppressor that is often lost in advanced $\mathrm{CaP}$. The loss of $\mathrm{Rb}$ contributes to tumor progression and androgen receptor activity in $\mathrm{CaP}$ [45] yet in inhibition of miR-30e* did not affect total Rb levels (Figure 5B). The importance of the loss of these genes as a function $\mathrm{CaP}$ progression in correlation with the increase in $\mathrm{miR}-30 \mathrm{e}^{*}$ throughout disease progression makes these predicted miR-30e* targets very interesting. NKIRAS1 is a potent inhibitor of NF- $\kappa \mathrm{B}$, although the role NKIRAS1 plays in $\mathrm{CaP}$ is not well elucidated; the regulation of $\mathrm{NF}-\kappa \mathrm{B}$ activation by miR-30 $e^{*}$ makes this interesting future direction.

miR-30 $*$ is not alone it its ability to regulate NF$\kappa \mathrm{B}$ activation. NF- $\kappa \mathrm{B}$ expression is directly affected by miR-9, which inhibits NFKB1 expression [11] and thus $\mathrm{NF}-\kappa \mathrm{B}$ activity. miR-9 is overexpressed in high grade $\mathrm{CaP}$ [46] thus is unlikely to contribute to an increase in NF- $\mathrm{BB}$ activation. Interestingly, miR-146 inhibits canonical NF$\kappa \mathrm{B}$ activation $[47,36]$ and is down regulated in $\mathrm{CaP}[36]$, suggesting that this pathways may also contribute to NF$\kappa \mathrm{B}$ activation in $\mathrm{CaP}$.

Docetaxel is an FDA approved therapy for hormone refractory prostate cancer and has been shown to improve life expectancy [34], yet it's efficacy as a monotherapy is blunted by high toxicity [47]. Docetaxel disrupts cell division by preventing depolymerization of microtubules [48]. Work by Domingo-Domenech et al. [13] has demonstrated that treatment of castration resistant $\mathrm{CaP}$ with docetaxel induces $\mathrm{NF}-\kappa \mathrm{B}$ activation, which contributes to resistance. Multiple $\mathrm{CaP}$ clinical trials have been completed treating patients with bortezomib a nonspecific NF- $\kappa \mathrm{B}$ inhibitor alone [49] or in combination with the chemotherapeutic docetaxel [50]. These trials have demonstrated that bortezomib alone was capable of slowing the rise of patient's prostate specific antigen (PSA) levels and the combination therapy was able to reduce tumor burden; although there is accompanying treatment toxicity [50]. Our studies indicate that inhibition of miR-30e* effectively lowers the minimal effective dose of docetaxel required to kill CaP cells (Figure 5E). Clinical trials using the RNAi and anti-miRs have demonstrated that durable inhibition is able to be achieved through chemical modification of the oligos. Thus, miR-30e* inhibition has the potential to provide a novel way to target NF- $\kappa \mathrm{B}$ hyper-activation in the clinic and provide a window for minimally toxic therapeutic intervention with docetaxel in $\mathrm{CaP}$ patients.

\section{MATERIALS AND METHODS}

\section{Animals and tumor system}

C57BL/6J mice were purchased from The Jackson Laboratory (Bar Harbor, ME) and Taconic Laboratory (Hudson, NY). TRansgenic Adenocarcinoma of Mouse Prostate (TRAMP) and SCID mice were bred and maintained at Roswell Park Cancer Institute (RPCI). Hi-MYC and corresponding FVB control mice were purchased from NCI (Frederick, MD) by Dr. Leigh Ellis (RPCI) and were processed and generously given to this study as a gift. All mice were male and housed in microisolator cages in a laminar flow unit under ambient light at $24^{\circ} \mathrm{C}$. The RPCI Institutional Animal Care and Use Committee (IACUC) approved all procedures and experiments for this study.

\section{Reagents and antibodies}

Insulin, dihydrotestosterone (DHT), LPS, cell lysis buffer, protease inhibitor cocktail and MTT were purchased from Sigma-Aldrich (St. Louis, MO). $\mathrm{NF}-\kappa \mathrm{B}$ p65 and Rb specific antibodies as well as the $\beta$-Galactosidase staining kit were purchased from Cell Signal (Beverly, MA). Ki-67 antibodies were purchase from Leica Biosystems (Buffalo Grove, IL). BAY 117085, phosphatase inhibitor cocktails $A$ and $B$ as well as antibodies specific for cyclin D-1, p-Rb and $\alpha$-tubulin were purchased from Santa Cruz Biotechnology (Dallas, Texas). Protein assay dye reagent concentrate used for Bradford assays as well as HRP for western blot color development was purchased from Bio-Rad (Hercules, California). DMEM, RPMI640, OPTI-MEM medias, Trypsin-EDTA $(0.05 \%)$, miR-30e* inhibitor oligos, miR-30e* specific qRTPCR primers, Pre-miR ${ }^{\mathrm{TM}}$ miRNA Precursor Molecules-Negative Control \#2, lipofectamine 2000, NuPAGE® Novex $® 10 \%$ Bis-Tris Protein Gels, Nitrocellulose Pre-Cut Blotting Membranes, TRIzol, mirVana $^{\mathrm{TM}}$ miRNA Isolation Kit as well as the mirVana ${ }^{\mathrm{TM}}$ qRT-PCR miRNA Detection Kit were all purchased from Thermo Fisher Scientific (Waltham, MA). Fetal Bovine Serum (FBS) was purchased from Atlanta Biologicals Inc. (Flowery Branch, GA). Tetracycline-free FBS and the pTetOne vector construct system were both purchased from Clonetech (Mountain View, CA). Luciferase reporter assays and passive lysis buffer were both purchased from Promega (Madison, WI). L-glutamine, penicillinstreptomycin and the selection agent hygromycin B were all purchased from Cellgro (Manassas, VA). Cell lysis buffer \#6 and the cleaved-caspase-3 ELISA kit were both purchased from R \& D Systems (Minneapolis, MN).

\section{Cell lines and growth conditions}

The murine $\mathrm{CaP}$ cell line TRAMP $\mathrm{C} 2 \mathrm{H}$ was a generous gift from Dr. Barbara Foster. TRAMP C2H cells were grown in TRAMP media (DMEM supplemented with $10 \% \mathrm{FBS}, 2.5 \mathrm{mg} / 500 \mathrm{~mL}$ insulin, $10^{-8} \mathrm{M}$ DHT, L-glutamine and penicillin-streptomycin) in tissue culture flasks at $37^{\circ} \mathrm{C}$ at $10 \% \mathrm{CO}^{2}$ [51]. The human $\mathrm{CaP}$ cell line PC-3M was purchased from American Type Culture Collection (ATCC; Manassas, VA) and cultured in RPMI640 supplemented with 10\% FBS as well as 
L-glutamine and penicillin-streptomycin. TRAMP C2H cells stably expressing pTetOne-NHA-miR-30e* sensitive$\mathrm{I} \kappa \mathrm{B} \alpha(\mathrm{WT} \mathrm{I} \kappa \mathrm{B} \alpha)$ or pTetOne-NHA-miR-30e* resistant $\mathrm{I} \kappa \mathrm{B} \alpha\left(\mathrm{miR}-30 \mathrm{e}^{*}\right.$ resistant $\mathrm{I} \kappa \mathrm{B} \alpha$ ) were grown in complete TRAMP media with $10 \%$ tetracycline-free FBS in tissue culture flasks in the presence of hygromycin B $(3 \mu \mathrm{g} / \mathrm{mL})$.

All cells were maintained and plated for experimentation by harvesting from tissue culture flasks using trypsin $\left(2 \mathrm{~mL} / 75 \mathrm{~cm}^{2}\right)$ and washed with sterile PBS; counted using a hemocytometer and then reseeded in tissue culture flasks or plates with fresh media.

Cells were transfected with miR-30e* inhibitor oligos, scramble oligos, I $\mathrm{B} \alpha$ super repressor, HA-tag wild type I $\kappa \mathrm{B} \alpha$ pTetOne or HA-tag miR-30e* resistant I $\kappa \mathrm{B} \alpha$ pTetOne using lipofectamine 2000 and OPTI-MEM according to the manufacturer's protocol.

\section{RNA isolation}

Ventral, dorsal and lateral prostates were harvested from 6-, 8-, 12- and 29-week old TRAMP mice and control C57BL/6J mice. Following resection, prostate samples were washed clean with PBS, weighed and flash frozen in eppendorf tubes. Prostates were then transferred to RNAse and DNAse free bags on dry ice and mechanically digested until prostates were a fine powder. The samples were then re-suspended in 10 volumes/tissue mass of cell lysis binding buffer. miRVana RNA isolation protocol provided by the manufacturer was used to harvest RNA. Ventral, dorsal and lateral prostates were harvested from 1-, 3-, 5-, 7- and 9-month old Hi-MYC and FVB controls using Mouse Tumor Model Resource (RPCI). Prostates were homogenized in $1 \mathrm{~mL}$ TRIzol and protocol provided by manufacturer was used to harvest RNA.

\section{Quantitative real-time PCR (qRT-PCR)}

qRT-PCR was performed using miRVana qRT-PCR miRNA Detection kit (Figure 1A) as well as iScript Select cDNA synthesis kit followed by SSO advanced SYBR qRTPCR reagents (Figure 1B) using primers specific for miR-30e* and U6 (Thermo Fisher Scientific, Waltham, MA). Raw data was analyzed using the $2-^{\Delta \mathrm{Cq}}$ formula.

\section{MTT assays}

TRAMP C2H cells were plated at concentration of $5 \times 10^{4}$ cells / well for day 1 and $2.5 \times 10^{4}$ cells / well for day 2 in duplicate for technical replicates and were plated at a concentration of $1 \times 10^{5}$ cells/well in 6 well plates. PC-3M cells were plated at a concentration of 2 x $10^{5}$ cells / well for day 1 and 1 x $10^{5}$ cells / well for day 2 in duplicate for technical replicate and were plated at a concentration of $2 \times 10^{5}$ cells/well in 6 well plates for Figure 3D. Cells were allowed to adhere overnight, washed with PBS and then $2 \mathrm{~mL}$ of complete media was added back to each well. Cells were then transfected with either a miR-30e* inhibitor or control scramble oligos or treated with Bay 11-7085 inhibitor. Twenty-four or 48 hours later $400 \mu \mathrm{L}$ of $5 \mathrm{mg} / \mathrm{mL} 3$-(4, 5-dimethylthiazol2-yl)-2, 5-diphenyltetrazolium bromide (MTT) was added to each well and left to develop in the dark at $37^{\circ} \mathrm{C}$ for 4 hours. Following the 4 hour development period formalin crystals in media were pelleted and suspended in $1 \mathrm{~mL}$ of acidified isopropanol, this was added to each well to dissolve crystals that were adherent to the plate. This was left to sit for 30 minutes shaking and then samples were mixed up and down via pipetting until thoroughly suspended. Two hundred $\mu \mathrm{L}$ from each sample were transferred to individual wells in a 96 well plate where absorbance at $570 \mathrm{nM}$ was recorded on a spectrophototer. Experimental values were normalized to scramble oligo treated controls.

\section{Senescence associated $\beta$ - gal staining}

TRAMP C2H cells were plated at a concentration of $5 \times 10^{4}$ cells / well in 6 well tissue culture plates. Cells were left to adhere overnight, rinsed with sterile PBS and then fresh media was added to each well. Cells were then transfected with miR-30e* inhibitor. Twenty-four hours later cells were rinsed with sterile PBS twice, fixed and treated with $\beta$-galatosidase staining solution overnight at $37^{\circ} \mathrm{C}$. Each condition was plated in duplicate and counted in triplicate under light microscopy 200x.

\section{Cleaved-caspase 3 ELISA}

TRAMP C2H cells were plated at $5 \times 10^{5}$ cells $/ 10$ $\mathrm{cm}$ tissue culture dish in $10 \mathrm{~mL}$ media. Cells were left to adhere overnight, rinsed with PBS and then fresh media was added. Cells were then transfected with miR-30e* inhibitor. Twenty-four hours later cells were rinsed with PBS twice and harvested. Protein lysates were generated using cell lysis buffer \#6 (R\&D Systems Minneapolis, $\mathrm{MN})$. The ELISA was purchased from R\&D Systems and run according to the provided protocol. One hundred and twenty-five $\mu \mathrm{g}$ of protein was used per well and all samples were run in duplicate.

\section{In vitro Tramp C2H Ki67 staining}

TRAMP C2H cells were plated at a concentration of $1 \times 10^{6}$ cells / $10 \mathrm{~cm}$ tissue culture dish in $10 \mathrm{~mL}$ media. Cells were left to adhere overnight, rinsed with PBS and then fresh media was added to each well. Cells were then transfected with miR-30e* inhibitor and 24 hours later cells were rinsed with sterile PBS twice and harvested. Cells were then pelleted, fixed in ice-cold ethanol, repelleted and then overlayed with agar. Tissues were processed and embedded in paraffin and then sectioned at 5 microns. Slides were de-parafinized in several baths of xylene and then rehydrated in graded alcohols followed by ddH2O. Slides were incubated in 1x pH6 
citrate buffer (Invitrogen, Grand Island, NY) for 20 minutes. Slides were washed, blocked and then stained with Ki67 antibody. For signal enhancement, $A B C$ reagent (Vector Labs, Burlingame, CA) was applied for 30 minutes. To reveal endogenous peroxidase activity, slides were incubated with DAB substrate (Dako, Carpinteria, CA) for 5 minutes and then counterstained with DAKO Hematoxylin for 20 seconds. Slides were dehydrated through several baths of graded alcohols and xylenes.

\section{NF- $\kappa$ B activity assay}

TRAMP C2H cells were plated in 6 well tissue culture plates at a concentration of $5 \times 10^{4}$ cells/ well. Cells were allowed to attach overnight and then transfected with $2.5 \mu \mathrm{g}$ of a NF- $\mathrm{kB}$ reporter luciferase construct. Six hours later cells were washed and then transfected with miR-30e* inhibitor for 24 hours. Cells were then washed in PBS and harvested in 500 $\mu \mathrm{L} 1 \mathrm{x}$ passive lysis buffer. Luciferase was quantified using promega luciferase assay kit on a luminometer. Experimental values were recorded relative to untreated control samples.

\section{Trypan blue exclusion assay}

TRAMP $\mathrm{C} 2 \mathrm{H}$ and PC3M cells were plated at a concentration of $2.5 \times 10^{4}$ cells / well and $2 \times 10^{5}$ cells / well respectively in 6 well plates and left to adhere overnight. Cells were washed with sterile PBS and 2 $\mathrm{mLs}$ of fresh media was added back to each well. Cells were then transfected with $2.5 \mu \mathrm{g}$ of IкB $\alpha$ super repressor construct using lipofectamine 2000 according to the manufacturers' protocol. Twenty-four hours later cells were harvested using Trypsin-EDTA (0.05\%) and counted via trypan blue exclusion on hemocytometers.

\section{Western blot}

To generate protein lysates cells were plated at $5 \times 10^{5}$ and left to adhere overnight on $10 \mathrm{~cm}$ dishes. Cells were harvested and incubated with cell lysis buffer supplemented with a protease inhibitor cocktail and phosphatase inhibitor cocktails A and B on ice for $30 \mathrm{~min}$. Lysates were pelleted at $14,000 \mathrm{rpm} / 20 \mathrm{~min}$ and the aqueous layer was harvested. The amount of protein was quantified using Bradford assays. Twenty $\mu \mathrm{g}$ of protein was run per sample on $10 \%$ bis-tris gels and then transferred to nitrocellulose membranes. Blots were probed with cyclin D-1, p-Rb, HA-tag, NF- $\mathrm{B}$ p 65 , or $\alpha$-tubulin specific antibodies. HRP development was recorded using a Bio-Rad imager and quantified using Quantity One software (Bio-Rad, Hercules, California). All values were normalized to $\alpha$-tubulin; experimental values were then normalized to control values.

\section{Tumor inoculation and doxycycline treatment}

miR-30e* resistant Tramp C2H cells were harvested from tissue culture flasks in vitro using Trypsin-EDTA $(0.05 \%)$ during log phase growth. Cells were washed $3 \mathrm{x}$ in sterile room temperature PBS and then resuspended at a concentration of $1 \times 10^{6} / 100 \mu \mathrm{L}$ in sterile PBS. Tumor cells were inoculated in $100 \mu \mathrm{L}$ subcutaneously in the flanks of C57BL/6 mice using $18 \mathrm{G}$ needles due to the large size of the cell line. Tumors were monitored via hand calipers and allowed to establish to $100 \mathrm{~mm}^{3}$ to control for tumor establishment variability and then experimental mice were fed doxycycline chow $(200 \mathrm{mg} / \mathrm{kg})$. Experimental endpoint was when the tumor volumes reached $800 \mathrm{~mm}^{3}$ in accordance with IACUC protocol.

\section{Tumor NF-кB p65, Ki67 and cyclin D1 immunohistochemistry}

miR-30e* resistant Tramp $\mathrm{C} 2 \mathrm{H}$ tumors were resected when tumor volume reached $800 \mathrm{~mm}^{3}$ from euthanized mice. Tumors were fixed overnight in $10 \%$ buffered formalin. Formalin-fixed paraffin sections were cut at $4 \mu \mathrm{m}$, placed on charged slides, and dried at $60^{\circ} \mathrm{C}$ for one hour. Slides were cooled to room temperature, deparaffinized in three changes of xylene, and rehydrated using graded alcohols. For antigen retrieval, slides were heated in a steamer for 30 minutes in citrate buffer $\mathrm{pH}=6$ (BioCare Medical; catalog \#CB910) and allowed to cool for 20 minutes. Endogenous peroxidase was quenched with aqueous $0.3 \% \mathrm{H} 2 \mathrm{O} 2$ for 10 minutes and washed with PBS/T. Slides were loaded on a Dako autostainer and serum free protein block (Dako; catalog \#X0909) was applied for 5 minutes, blown off, and the Ki67 antibody (Thermo Scientific; catalog\# RM-9106-S1) was applied at $1 / 150(1 \mu \mathrm{g} / \mathrm{ml} \mathrm{Rb} \mathrm{IgG)} \mathrm{or} \mathrm{Cyclin} \mathrm{D1} \mathrm{antibody} \mathrm{(Abcam;}$ catalog \#ab16663) applied at 1/100 (1 $\mu \mathrm{g} / \mathrm{ml} \mathrm{Rb} \mathrm{IgG)}$ for one hour or NF-kB p65 antibody (Abcam; catalog \#ab7970) was applied at $1 / 4000(0.05 \mathrm{ug} / \mathrm{mL} \mathrm{Rb} \mathrm{IgG)} \mathrm{over}$ night at 4 degrees C. Biotinylated goat anti-rabbit (Vector Labs; catalog \#BA-1000) was then applied for 30 minutes followed by Elite ABC (Vector Labs; catalog\# PK6100) for 30 minutes or rabbit envision/ labeled polymer HRP anti-rabbit (Dako; catalog \#K4003) was then applied for 30 minutes. DAB (Dako; catalog \#K3468) applied for 5 minutes, was used for chromogen visualization. Lastly, the slides were counterstained with Hematoxylin, dehydrated, cleared and cover slipped. Slides were scanned and digitalized using Aperio Digital Pathology Slide Scanner (Leica). Quantification of IHC was performed by visually counting positively stained cells in sections from slides that had been digitalized via the Aperio Digital Pathology Slide Scanner (Leica). Cells that displayed positive staining for Ki-67 and cyclin-d1 were quantified while NF- $\kappa$ B p65 staining was only counted when it colocalized with the nuclear staining. Three sections from each 
tumor were quantified for Ki-67 and cyclin D1 while five sections from each tumor were quantified for NF- $\kappa \mathrm{B}$ p65.

\section{ACKNOWLEDGMENTS}

The authors thank S. Sass, K. Ramsey, P. Meir, S. Olejniczak Ph.D and the pathology resource network for technical assistance and discussion.

\section{CONFLICTS OF INTEREST}

No potential conflicts of interest were disclosed.

\section{GRANT SUPPORT}

This work was supported by National Cancer Institute grant CA55791 (S.O.G.). S.M.E. was supported by National Cancer Institute T32 grant (CA085183) and in part by the Roswell Park Cancer Center Support Grant (CA16056).

\section{REFERENCES}

1. Siegel RL, Miller KD, Jemal A. Cancer statistics, 2015. CA Cancer J Clin. 2015; 65:5-29.

2. Gomella LG, Singh J, Lallas C, Trabulsi EJ. Hormone therapy in the management of prostate cancer: evidencebased approaches. Ther Adv Urol. 2010; 2:171-181.

3. Sfanos KS, De Marzo AM. Prostate cancer and inflammation: the evidence. Histopathology. 2012; 60:199-215.

4. Smith PC, Hobisch A, Lin DL, Culig Z, Keller ET. Interleukin-6 and prostate cancer progression. Cytokine Growth Factor Rev. 2001; 12:33-40.

5. Balk SP, Knudsen KE, AR. The cell cycle, and prostate cancer. Nucl Recept Signal. 2008; 6:e001.

6. Karin M. NF-kappaB as a critical link between inflammation and cancer. Cold Spring Harb Perspect Biol. 2009; 1:a000141.

7. Perkins ND. Integrating cell-signalling pathways with NF-kappaB and IKK function. Nat Rev Mol Cell Biol. 2007; 8:49-62.

8. Suh J, Rabson AB. NF-kappaB activation in human prostate cancer: important mediator or epiphenomenon? J Cell Biochem. 2004; 91:100-117.

9. Xiao G, Fu J. NF-kappaB and cancer: a paradigm of YinYang. Am J Cancer Res. 2011; 1:192-221.

10. Suh J, Payvandi F, Edelstein LC, Amenta PS, Zong WX, Gelinas C, Rabson AB. Mechanisms of constitutive NF-kappaB activation in human prostate cancer cells. Prostate. 2002; 52:183-200.

11. Hoesel B, Schmid JA. The complexity of NF-kappaB signaling in inflammation and cancer. Mol Cancer. 2013; $12: 86$.
12. Lessard L, Karakiewicz PI, Bellon-Gagnon P, AlamFahmy M, Ismail HA, Mes-Masson AM, Saad F. Nuclear localization of nuclear factor-kappaB p65 in primary prostate tumors is highly predictive of pelvic lymph node metastases. Clin Cancer Res. 2006; 12:5741-5745.

13. Domingo-Domenech J, Mellado B, Ferrer B, Truan D, Codony-Servat J, Sauleda S, Alcover J, Campo E, Gascon P, Rovira A, Ross JS, Fernandez PL, Albanell J. Activation of nuclear factor-kappaB in human prostate carcinogenesis and association to biochemical relapse. Br J Cancer. 2005; 93:1285-1294.

14. Jin R, Yi Y, Yull FE, Blackwell TS, Clark PE, Koyama T, Smith JA Jr, Matusik RJ. NF-kappaB gene signature predicts prostate cancer progression. Cancer Res. 2014; 74:2763-2772.

15. Codony-Servat J, Marin-Aguilera M, Visa L, GarciaAlbeniz X, Pineda E, Fernandez PL, Filella X, Gascon P, Mellado B. Nuclear factor-kappa B and interleukin-6 related docetaxel resistance in castration-resistant prostate cancer. Prostate. 2013; 73:512-521.

16. Shukla S, Maclennan GT, Fu P, Patel J, Marengo SR, Resnick MI, Gupta S. Nuclear factor-kappaB/p65 (Rel A) is constitutively activated in human prostate adenocarcinoma and correlates with disease progression. Neoplasia. 2004; 6:390-400.

17. Tse BW, Scott KF, Russell PJ. Paradoxical roles of tumour necrosis factor-alpha in prostate cancer biology. Prostate Cancer. 2012; 2012:128965.

18. Comstock CE, Revelo MP, Buncher CR, Knudsen KE. Impact of differential cyclin D1 expression and localisation in prostate cancer. Br J Cancer. 2007; 96:970-979.

19. The Cancer Genome Atlas; http://cancergenome.nih.gov/.

20. Robinson D, Van Allen EM, Wu YM, Schultz N, Lonigro RJ, Mosquera JM, Montgomery B, Taplin ME, Pritchard CC, Attard G, Beltran H, Abida W, Bradley RK, et al. Integrative clinical genomics of advanced prostate cancer. Cell. 2015; 161:1215-1228.

21. Bartel DP. MicroRNAs: genomics, biogenesis, mechanism, and function. Cell. 2004; 116:281-297.

22. Fabbri M, Croce CM, Calin GA. MicroRNAs. Cancer J. 2008; 14:1-6.

23. Kim WT, Kim WJ. MicroRNAs in prostate cancer. Prostate Int. 2013; 1:3-9.

24. Sayed D, Abdellatif M. MicroRNAs in development and disease. Physiol Rev. 2011; 91:827-887.

25. Leung AK, Sharp PA. MicroRNA functions in stress responses. Mol Cell. 2010; 40:205-215.

26. Taganov KD, Boldin MP, Chang KJ, Baltimore D. NF-kappaB-dependent induction of microRNA miR146, an inhibitor targeted to signaling proteins of innate immune responses. Proc Natl Acad Sci U S A. 2006; 103:12481-12486.

27. Jiang L, Lin C, Song L, Wu J, Chen B, Ying Z, Fang L, Yan X, He M, Li J, Li M. MicroRNA-30e* promotes 
human glioma cell invasiveness in an orthotopic xenotransplantation model by disrupting the NF-kappaB/ IkappaBalpha negative feedback loop. J Clin Invest. 2012; 122:33-47.

28. Ma X, Becker Buscaglia LE, Barker JR, Li Y. MicroRNAs in NF-kappaB signaling. J Mol Cell Biol. 2011; 3:159-166.

29. Gingrich JR, Barrios RJ, Foster BA, Greenberg NM. Pathologic progression of autochthonous prostate cancer in the TRAMP model. Prostate Cancer Prostatic Dis. 1999; 2:70-75.

30. Ellwood-Yen K, Graeber TG, Wongvipat J, Iruela-Arispe ML, Zhang J, Matusik R, Thomas GV, Sawyers CL. Mycdriven murine prostate cancer shares molecular features with human prostate tumors. Cancer Cell. 2003; 4:223-238.

31. Iwata T, Schultz D, Hicks J, Hubbard GK, Mutton LN, Lotan TL, Bethel C, Lotz MT, Yegnasubramanian S, Nelson WG, Dang CV, Xu M, Anele U, et al. MYC overexpression induces prostatic intraepithelial neoplasia and loss of Nkx3.1 in mouse luminal epithelial cells. PLoS One. 2010; 5:e9427.

32. Vermeulen K, Van Bockstaele DR, Berneman ZN. The cell cycle: a review of regulation, deregulation and therapeutic targets in cancer. Cell Prolif. 2003; 36:131-149.

33. Ott MM, Bartkova J, Bartek J, Durr A, Fischer L, Ott G, Muller-Hermelink HK, Kreipe H. Cyclin D1 expression in mantle cell lymphoma is accompanied by downregulation of cyclin D3 and is not related to the proliferative activity. Blood. 1997; 90:3154-3159.

34. Sartor AO. Progression of metastatic castrate-resistant prostate cancer: impact of therapeutic intervention in the post-docetaxel space. J Hematol Oncol. 2011; 4:18.

35. Lee OK, Cha HJ, Lee MJ, Lim KM, Jung JW, Ahn KJ, An IS, An S, Bae S. Implication of microRNA regulation in para-phenylenediamine-induced cell death and senescence in normal human hair dermal papilla cells. Mol Med Rep. 2015; 12:921-936.

36. Mortensen MM, Hoyer S, Orntoft TF, Sorensen KD, Dyrskjot L, Borre M. High miR-449b expression in prostate cancer is associated with biochemical recurrence after radical prostatectomy. BMC Cancer. 2014; 14:859.

37. Cancer Genome Atlas Research Network. The molecular taxonomy of primary prostate cancer. Cell. 2015; 163:1011-1025.

38. Patel N, Tahara SM, Malik P, Kalra VK. Involvement of miR-30c and miR-301a in immediate induction of plasminogen activator inhibitor-1 by placental growth factor in human pulmonary endothelial cells. Biochem J. 2011; 434:473-482.

39. Liao Y, Lonnerdal B. Beta-catenin/TCF4 transactivates miR-30e during intestinal cell differentiation. Cell Mol Life Sci. 2010; 67:2969-2978.
40. Downing SR, Russell PJ, Jackson P. Alterations of p53 are common in early stage prostate cancer. Can J Urol. 2003; 10:1924-1933.

41. Hosako H, Martin GS, Barrier M, Chen YA, Ivanov IV, Mirkes PE. Gene and microRNA expression in p53deficient day 8.5 mouse embryos. Birth Defects Res A Clin Mol Teratol. 2009; 85:546-555.

42. Roberts E, Cossigny DA, Quan GM. The role of vascular endothelial growth factor in metastatic prostate cancer to the skeleton. Prostate Cancer. 2013; 2013:418340.

43. Wang S, Gao J, Lei Q, Rozengurt N, Pritchard C, Jiao J, Thomas GV, Li G, Roy-Burman P, Nelson PS, Liu X, Wu H. Prostate-specific deletion of the murine Pten tumor suppressor gene leads to metastatic prostate cancer. Cancer Cell. 2003; 4:209-221.

44. Hubner A, Mulholland DJ, Standen CL, Karasarides M, Cavanagh-Kyros J, Barrett T, Chi H, Greiner DL, Tournier C, Sawyers CL, Flavell RA, Wu H, Davis RJ. JNK and PTEN cooperatively control the development of invasive adenocarcinoma of the prostate. Proc Natl Acad Sci U S A. 2012; 109:12046-12051.

45. Sharma A, Yeow WS, Ertel A, Coleman I, Clegg N, Thangavel C, Morrissey C, Zhang X, Comstock CE, Witkiewicz AK, Gomella L, Knudsen ES, Nelson PS, Knudsen KE. The retinoblastoma tumor suppressor controls androgen signaling and human prostate cancer progression. J Clin Invest. 2010; 120:4478-4492.

46. Walter BA, Valera VA, Pinto PA, Merino MJ. Comprehensive microRNA profiling of prostate cancer. $\mathrm{J}$ Cancer. 2013; 4:350-357.

47. Sinibaldi VJ. Docetaxel treatment in the elderly patient with hormone refractory prostate cancer. Clin Interv Aging. 2007; 2:555-560.

48. Morse DL, Gray H, Payne CM, Gillies RJ. Docetaxel induces cell death through mitotic catastrophe in human breast cancer cells. Mol Cancer Ther. 2005; 4:1495-1504.

49. Kraft AS, Garrett-Mayer E, Wahlquist AE, Golshayan A, Chen CS, Butler W, Bearden J, Lilly M. Combination therapy of recurrent prostate cancer with the proteasome inhibitor bortezomib plus hormone blockade. Cancer Biol Ther. 2011; 12:119-124.

50. Hainsworth JD, Meluch AA, Spigel DR, Barton J Jr, Simons L, Meng C, Gould B, Greco FA. Weekly docetaxel and bortezomib as first-line treatment for patients with hormone-refractory prostate cancer: a Minnie Pearl Cancer Research Network phase II trial. Clin Genitourin Cancer. 2007; 5:278-283.

51. Foster BA, Gingrich JR, Kwon ED, Madias C, Greenberg NM. Characterization of prostatic epithelial cell lines derived from transgenic adenocarcinoma of the mouse prostate (TRAMP) model. Cancer Res. 1997; 57:3325-3330. 